\title{
KARAKTERISTIK ARUS DI PERAIRAN SEKITAR KAWASAN KELURAHAN SARIO TUMPAAN TELUK MANADO
}

\section{(Characteristics of Coastal Current in Sario Tumpaan Waters-Manado Bay)}

\author{
Salvatore a'Paulo Narahawarin ${ }^{1}$, Rignolda Djamaluddin ${ }^{1}$, P. A. Angmalisang ${ }^{1}$ \\ ${ }^{1}$ Program Studi Ilmu Kelautan, Fakultas Perikanan dan Ilmu Kelautan, \\ Universitas Sam Ratulangi, Manado.
}

\begin{abstract}
Since 1990s the development of Manado City started to be focused on coastal areas. Reclamation activities have an impact on the movement of water masses in the coastal region at certain level. Periodic monitoring of the oceanographic conditions around the coastal areas of reclaimed land is considered to be of importance to examine the extent to which changes have occurred through determination of current direction and speed and analysis the current dynamics under final quarters and full moon periods. By applying lagrangian method, several important points regarding to characteristic of prevailing current in the observed area were found. In the period of month of end quarters the resultant flow velocity measured at low and spring tide varies between 0.70 to 1.40 knots. At low tide, flow leads to the West and Northwest, compared to the West and Southwest at spring tide. In the full moon period resultant flow velocity measured at low and spring tide varies between 0.70 to 1.09 knots. At low flows generally leads to the North and Northwest, which is different from situation at spring tide to the West. Generally, current direction in Sario Tumpaan coastal water at low and spring tide is always to the sea with relative directions to the Southwest, West and Northwest.
\end{abstract}

Keywords: tidal, surface flow, Manado bay

Sejak era 1990an pembangunan di Kota Manado mulai difokuskan di wilayah pesisir. Kegiatan reklamasi memberikan dampak terhadap pergerakan massa air terutama di kawasan pantai pada skala tertentu. Pemantauan secara berkala terhadap kondisi oseanografis kawasan pantai sekitar lahan reklamasi dipandang penting dilakukan untuk mencermati sejauh mana perubahan telah terjadi dengan menentukan arah dan kecepatan arus serta menganalisis dinamika arus yang berlaku saat bulan kuartir akhir dan bulan purnama. Dengan menerapkan metode lagrangian ditemukan beberapa hal penting terkait karakteristik arus yang berlaku pada kawasan yang diobservasi. Pada periode bulan kuartir akhir, kecepatan resultan arus yang terukur saat surut dan pasang bervariasi diantara 0,70 sampai 1,40 knot. Saat surut arus mengarah ke Barat dan Barat Laut sedangkan saat pasang mengarah ke Barat dan Barat Daya. Pada periode bulan Purnama kecepatan resultan arus yang terukur saat surut dan pasang bervariasi diantara 0,70 sampai 1,09 knot. Saat surut umumnya arus mengarah ke Barat Laut dan Utara, berbeda dengan waktu pasang dimana arah arus ke Barat. Arah arus di perairan Sario Tumpaan saat pergerakan air pasang dan surut selalu mengarah ke laut dengan arah relatif ke Barat Daya, Barat dan Barat Laut.

Kata kunci: pasang surut, aliran permukaan, Teluk Manado 


\section{PENDAHULUAN}

Indonesia sebagai Negara kepulauan memiliki kurang lebih 17.845 pulau dengan panjang garis pantai 81.000 $\mathrm{km}$. Dalam perkembangannya, arah pembangunan banyak diarahkan kewilayah pesisir yang antara lain dimanfaatkan untuk peruntukan kawasan pemukiman, pusat pemerintahan, industri, pelabuhan, dan parawisata sebagaimana dikemukan Triatmodjo(1999).

Sejak era 1990an pembangunan di Kota Manado mulai difokuskan di wilayah pesisir sepanjang Teluk Manado untuk mendukung pengembangan sector bisnis. Pasca pembangunan Jl. PiereTendean (Boulevard) kawasan pantai mulai direklamasi.

Secara oseanografi, kegiatan reklamasi memberikan dampak terhadap pergerakan massa air terutama di kawasan pantai pada skala tertentu. Hal ini dapat disebabkan karena hilangnya lahan gisik dan perubahan morfologi pantai.

Secara umum, Wyrtki (1961) dalam petanya menggambarkan pola pergerakan arus di perairan sekitarTeluk Manado dipengaruhi oleh Musim Barat dan Musim Timur. Pada musim Barat arus bergerak dari arah Utara, sedangkan pada saat musim Timur, arus bergerak dari arah Selatan. Sementara itu, Rampengan (2009) menginformasikan bahwa pergerakan arus di Teluk Manado yang utama terjadi di bagian tengah berupa pergerakan massa air masuk dan keluar. Sirkulasi massa air pada ruangruang lainnya tampaknya hanya merupakan akibat dari kejadian pada ruang utama tersebut. Dalam penelitian lain, Ariston (2010) melaporkan bahwa arus di Teluk Manado lebih banyak bergerak ke Barat dan Barat Laut atau mengarah keluar dari Teluk Manado.
Pemantauan secara berkala terhadap kondisi oseanografis kawasan pantai sekitar lahan reklamasi dipandang penting dilakukan untuk mencermati sejauh mana perubahan telah terjadi. Berkaitan dengan hal tersebut, penelitian ini dilakukan dan dirancang secara terbatas untuk menelaah aspek karakteristik arus di perairan sekitar Kelurahan Sario Tumpaan yang telah menjadi obyek reklamasi sejak era 1990an untuk pengembangan kawasan bisnis.

Karakteristik arus di kawasan pantai sekitar Sario Tumpaan telah mengalami perubahan pada skala tertentu akibat adanya reklamasi. Karakteristik arus yang saat ini berlaku dipandang sebagai konsekuensi perubahan tersebut. Seperti apa karakteristik arus yang berlaku di kawasan ini kemudian diteliti secara terbatas melalui penelitian ini.

Secara khusus penelitian ini bertujuan untuk menentukan arah dan kecepatan arus serta menganalisis dinamika arus yang berlaku saat bulan kuartir akhir dan bulan purnama.

\section{METODE PENELITIAN}

Secara umum, penelitian ini menggunakan metode deskriptif. Data pengamatan di lapangan berupa hasil pengukuran arus dan pasang surut (pasut) diolah dan dianalisis di Laboratorium Morfologi Pantai dan HidroOseanografi. Dalam penelitian ini pengukuran arus dan pasut dilaksanakan selama 2 hari, yakni 1 hari saat periode bulan kuartir akhir dan 1 hari saat periode bulan purnama, dengan mengikuti periode pasang dan periode waktu surut. Pengukuran arus dikerjakan dengan menerapkan metode Lagrangian seperti disarankan dalam Pickard dan Emery (1982). Sedangkan pengukuran 
pasut menggunakan metode pengamatan langsung.

Pengolahan dan analisis data dilakukan dengan bantuan komputer yang difasilitasi program Canvas 11 dan program Surfer. Nilai kecepatan arus dihitung dengan menggunakan rumus "Trigonometri" sederhana yang lazim diaplikasikan ke dalam penghitungan vektor, seperti berikut ini :

$$
\begin{aligned}
& Z^{2}{ }_{1-2}=X_{1-2}^{2}+Y_{1-2}^{2}(3.1) \\
& Z_{1-2}=\sqrt{X_{1-2}^{2}+Y_{1-2}^{2}}(3.2) \\
& Z^{2}{ }_{2-3}=X_{2-3}^{2}+Y_{2-3}^{2}(3.3) \\
& Z_{2-3}=\sqrt{X_{2-3}^{2}+Y_{2-3}^{2}}(3.4)
\end{aligned}
$$

Dengan mengikuti persamaan 3.1 sampai 3.4, maka untuk memperoleh nilai $X$ dan $Y$ yang diletakkan dalam koordinat Cartesius menggunakan rumus berikut :

$$
\begin{aligned}
& X_{1-2}=X_{2}-X_{1} \\
& Y_{1-2}=Y_{2}-Y_{1} \\
& X_{2-3}=X_{3}-X_{2} \\
& Y_{2-3}=Y_{3}-Y_{2}
\end{aligned}
$$

dimana :

$Z_{1-2}=$ jarak tempuh dari koordinat pertama dan kedua $(\mathrm{m})$

$\mathrm{Z}_{2-3}=$ jarak tempuh dari koordinat kedua dan ketiga $(\mathrm{m})$

$\mathrm{X}_{1-2}=$ jarak tempuh dari koordinat bujur pertama dan kedua $(\mathrm{m})$

$\mathrm{X}_{2-3}=$ jarak tempuh dari koordinat bujur kedua dan ketiga $(\mathrm{m})$

$\mathrm{Y}_{1-2}=$ jarak tempuh dari koordinat lintang pertama dan kedua $(\mathrm{m})$

$\mathrm{Y}_{2-3}=$ jarak tempuh dari koordinat lintang kedua dan ketiga $(\mathrm{m})$

$\mathrm{X}_{1}=$ koordinat bujur pertama
$\mathrm{X}_{2}=$ koordinat bujur kedua

$\mathrm{X}_{3}=$ koordinat bujur ketiga

$Y_{1}=$ koordinat lintang pertama

$\mathrm{Y}_{2}=$ koordinat lintang kedua

$\mathrm{Y}_{3}=$ koordinat lintang ketiga

Untuk perhitungan kecepatan arus dapat menggunakan rumus seperti petunjuk kecepatan, sebagai berikut :

$\mathrm{V}=\mathrm{ds} / \mathrm{dt}$

dimana :

$\mathrm{V}=$ peubah kecepatan arus $(\mathrm{m} / \mathrm{s})$

$\mathrm{S}=$ jarak yang ditempuh (nilai dari Z) (m)

$\mathrm{t}=$ waktu yang ditempuh dari tiap koordinat (det)

Sedangkan untuk arah arus diperoleh dengan mencari sudut alpha menggunakan formula "Degrees" (derajat) terlebih dahulu, dengan mengaplikasikan rumus yang sebelumnya menjadi :

$\alpha\left(0^{\circ}\right)=\left|\arctan \left(\mathrm{Z}_{2-3} / \mathrm{Z}_{1-2}\right)\right|$

Dengan mengikuti syarat kondisi sebagai berikut :

1. Jika $Z_{1-2}=+; Z_{2-3}=+$; Maka $X_{2-3}>$ $X_{1-2}$ dan $Y_{2-3}>Y_{1-2}$

2. Jika $Z_{1-2}=+; Z_{2-3}=-$; Maka $X_{2-3}>$ $X_{1-2}$ dan $Y_{2-3}<Y_{1-2}$

3. Jika $Z_{1-2}=-; Z_{2-3}=-$; Maka $X_{2-3}<$ $X_{1-2}$ dan $Y_{2-3}<Y_{1-2}$

4. Jika $Z_{1-2}=-; Z_{2-3}=+$; Maka $X_{2-3}<$ $X_{1-2}$ dan $Y_{2-3}>Y_{1-2}$

Dengan ketentuan nilai $Z(-/+)$ untuk menentukan arah pergerakan.Adapun syarat yang digunakan sebagai berikut :

1. Arah $=90^{\circ}-\alpha$, jika $X_{2-3}>X_{1-2}$ dan $Y_{2-}$ ${ }_{3}>Y_{1-2}$

2. Arah $=90^{\circ}+\alpha$, jika $X_{2-3}>X_{1-2}$ dan $Y_{2-}$ $3<\mathrm{Y}_{1-2}$

3. Arah $=270^{\circ}-\alpha$, jika $X_{2-3}<X_{1-2}$ dan $Y_{2-}$ $3<\mathrm{Y}_{1-2}$

4. Arah $=270^{\circ}+\alpha$, jika $X_{2-3}>X_{1-2}$ dan $Y_{2-3}>Y_{1-2}$

5. Arah $=0^{\circ}$, jika $X_{2-3}=X_{1-2}$ dan $Y_{2-3}>$ $\mathrm{Y}_{1-2}$ 


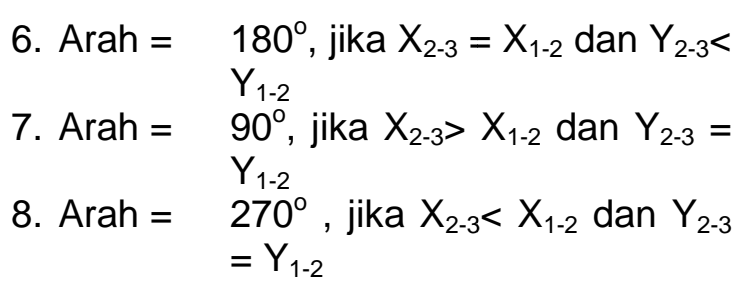

\section{HASIL DAN PEMBAHASAN}

Hasil pengukuran pertama 2 Juni 2012 saat bulan kuartir akhir, permukaan air laut mulai bergerak pasang dari pukul 11.00 dengan tinggi muka laut $29 \mathrm{~cm}$ dan mulai bergerak surut dari pukul 18.00 dengan tinggi muka laut $141 \mathrm{~cm}$.Dari hasil pengamatan, diperoleh bahwa pasang tertinggi terjadi pada pukul 17.00 dengan tinggi muka laut $158 \mathrm{~cm}$ dan surut terendah mencapai $29 \mathrm{~cm}$ pada pukul 11.00.

Pengukuran kedua 3 juni 2012 permukaan air laut mulai bergerak pasang dari pukul 01.00 dengan tinggi muka laut $117 \mathrm{~cm}$ dan mulai bergerak surut dari pukul 05.00 dengan tinggi muka laut 220 $\mathrm{cm}$. Dari hasil pengamatan pasang tertinggi yang teramati dengan tinggi muka laut $237 \mathrm{~cm}$ adalah terjadi pada pukul 04.00 dan surut terendah pada pukul 10.00 dengan tinggi muka laut 40 $\mathrm{cm}$. Secara deskriptif kondisi pasut yang teramati ditampilkan dalam Gambar 1.

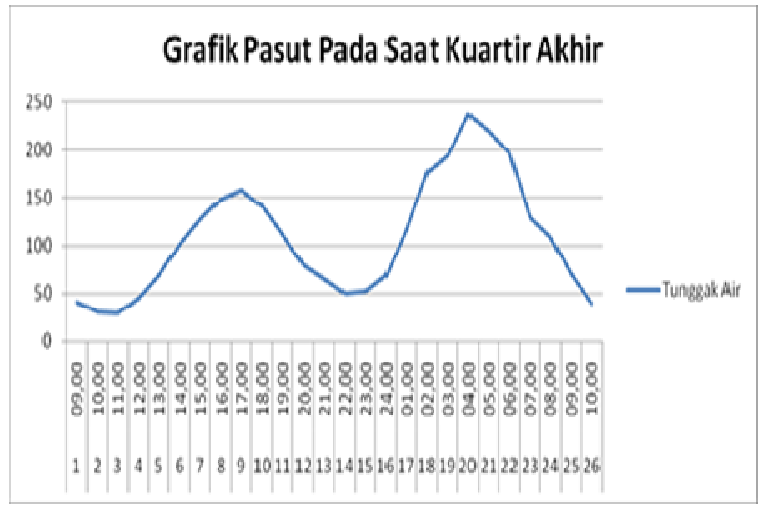

Gambar 1. Grafik Pasang Surut Pada Saat Bulan Kuartir Akhir.

\section{Tabel 1. Kecepatan Arus Saat Pasang dan Surut Pada Bulan Kuartir Akhir.}

\begin{tabular}{|c|c|c|c|c|}
\hline \multirow{2}{*}{$\begin{array}{c}\text { Waktu } \\
\text { Pengukuran }\end{array}$} & $\mathbf{Z 1 - 2}$ & \multirow{2}{*}{$\begin{array}{c}\text { Kecepatan } \\
\text { dalam Knot }\end{array}$} & $\begin{array}{c}\text { Jarak } \\
\text { Z(1-2) }\end{array}$ \\
\cline { 2 - 3 } & $\begin{array}{c}\text { Jarak } \\
\text { (meter) }\end{array}$ & $\begin{array}{c}\text { Kecepatan } \\
\text { (Meter) }\end{array}$ & & $\theta$ \\
\hline 13.35 & 88.29 & 0.724 & 1.40 & 45.18 \\
\hline 13.45 & 45.65 & 0.374 & 0.73 & 54.78 \\
\hline 14.00 & 50.02 & 0.410 & 0.80 & 64.57 \\
\hline 14.15 & 43.81 & 0.359 & 0.70 & 63.43 \\
\hline 14.25 & 43.88 & 0.360 & 0.70 & 45.00 \\
\hline 14.35 & 44.38 & 0.364 & 0.71 & 12.53 \\
\hline 17.05 & 45.16 & 0.370 & 0.72 & 45.00 \\
\hline 17.20 & 45.11 & 0.370 & 0.72 & 87.14 \\
\hline 17.30 & 45.72 & 0.375 & 0.73 & 45.00 \\
\hline 17.40 & 44.81 & 0.367 & 0.71 & 67.38 \\
\hline 17.40 & 44.24 & 0.363 & 0.70 & 63.43 \\
\hline 18.00 & 48.72 & 0.399 & 0.77 & 84.64 \\
\hline
\end{tabular}

Hasil pengolahan data arus ditemukan kecenderungan bahwa kondisi arus pada kawasan studi berkaitan erat dengan faktor pasut. Hasil pengukuran menunjukkan bahwa kecepatan arus bervariasi antara 0,359 - 0,724m/det. Kecepatan arus terlemah 0,359 m/det atau sekitar 0,70 knot dan tercepat sebesar $0,724 \mathrm{~m} / \mathrm{det}$ atau 1,40 knot diperoleh pada saat air bergerak surut. Selanjutnya saat air bergerak pasang kecepatan arus yang terukur adalah sebesar 0,363 $\mathrm{m} / \mathrm{det}$ sampai dengan 0,399 $\mathrm{m} /$ det. Kecepatan arus terlemah adalah $0,363 \mathrm{~m} /$ det atau $0,70 \mathrm{knot}$ dan tercepat 0,399 atau 0,77 knot. Gambaran detil kecepatan arus adalah seperti dalam Tabel 1.

Hasil pengukuran pertama tanggal 4 Juni 2012 pada Saat bulan Purnama air laut mulai bergerak pasang saat pukul 13.00 dengan tinggi muka laut $6 \mathrm{~cm}$ dan mulai bergerak surut dari pukul 19.00 dengan tinggi muka laut $138 \mathrm{~cm}$. Dari keseluruhan data, ditemukan bahwa pasang tertinggi terjadi pada pukul 18.00 dengan tinggi muka laut $144 \mathrm{~cm}$ dan surut terendah mencapai $5 \mathrm{~cm}$ pada pukul 12.00.

Pengukuran kedua 5 juni 2012, air laut mulai bergerak pasang saat pukul 


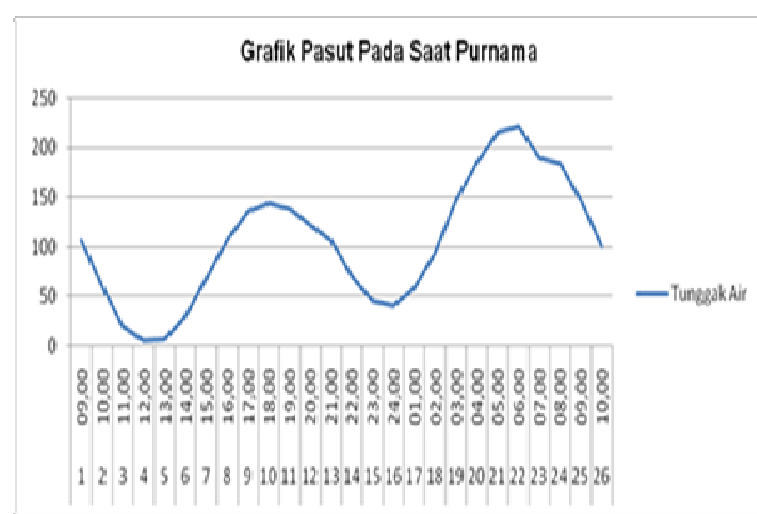

\section{Gambar 2. Grafik PasangSurut Pada Saat BulanPurnama.}

01.00 dengan tinggi muka laut $58 \mathrm{~cm}$ dan mulai bergerak surut saat pukul 07.00 dengan tinggi muka laut $117 \mathrm{~cm}$. Pasang tertinggi dengan tinggi muka laut $222 \mathrm{~cm}$ adalah terjadi pada pukul 06.00 dan surut terendah pada pukul 01.00 dengan tinggi muka laut $58 \mathrm{~cm}$. Selanjutnya hasil analisis secara deskriptif ditampilkan seperti Gambar 2.

Hasil pengolahan data arus permukaan, kecepatan arus pada saat bulan purnama tanggal 4 Juni 2012. Ditemukan kecepatan arus yang terukur bervariasi dengan kecepatan 0,359 sampai $0,380 \mathrm{~m} /$ det. Kecepatan arus terlemah adalah $0,359 \mathrm{~m} / \mathrm{det}$ atau 0,70 knot, dan tercepat mencapai $0,561 \mathrm{~m} / \mathrm{det}$ atau 1,09 knot saat air surut. Pada saat pasang, kecepatan arus bervariasi mulai dari $0,359 \mathrm{~m} /$ det sampai $0,380 \mathrm{~m} / \mathrm{det}$ dengan kecepatan terlemah $0,359 \mathrm{~m} / \mathrm{det}$ atau $0,70 \mathrm{knot}$ dan tercepat $0,380 \mathrm{~m} / \mathrm{det}$ atau 0,74 knot. Untuk lebih jelas, hasil pengukuran kecepatan arus saat bulan purnama ditampilkan seperti pada Tabel 2.

Dilihat dari karakteristik gerakan muka lautnya, pasang surut di indonesia dapat dibagi menjadi empat jenis yakni pasang surut harian tunggal (diurnal tide), harian ganda (semidiurnal tide) dan dua jenis campuran (mixed tide). Pada jenis

\section{Tabel 2. Kecepatan Arus Saat Pasang dan Surut Pada Bulan Purnama.}

\begin{tabular}{|c|c|c|c|c|}
\hline \multirow[t]{2}{*}{$\begin{array}{c}\text { Waktu } \\
\text { Pengukuran }\end{array}$} & Z1-2 & \multirow{2}{*}{$\begin{array}{c}\text { Kecepatan } \\
\text { (Meter) }\end{array}$} & \multirow{2}{*}{$\begin{array}{l}\text { Kecepatan } \\
\text { dalam Knot }\end{array}$} & $\begin{array}{l}\text { Jarak } \\
\mathrm{Z}(1-2)\end{array}$ \\
\hline & $\begin{array}{c}\text { Jarak } \\
\text { (meter) }\end{array}$ & & & $\theta$ \\
\hline 10.45 & 68.42 & 0.561 & 1.09 & 18.16 \\
\hline 11.00 & 44.95 & 0.368 & 0.71 & 24.78 \\
\hline 11.20 & 44.31 & 0.363 & 0.70 & 45.00 \\
\hline 11.35 & 43.81 & 0.359 & 0.70 & 63.43 \\
\hline 11.55 & 43.81 & 0.359 & 0.70 & 63.43 \\
\hline 12.00 & 43.81 & 0.359 & 0.70 & 26.57 \\
\hline 15.45 & 46.38 & 0.380 & 0.74 & 73.30 \\
\hline 16.00 & 43.81 & 0.359 & 0.70 & 26.57 \\
\hline 16.15 & 44.38 & 0.364 & 0.71 & 69.44 \\
\hline 16.35 & 44.24 & 0.363 & 0.70 & 82.87 \\
\hline 16.50 & 44.03 & 0.361 & 0.70 & 11.31 \\
\hline 17.05 & 43.88 & 0.360 & 0.70 & 71.57 \\
\hline
\end{tabular}

harian tunggal hanya terjadi satu kali pasang dan satu kali surut setiap hari, pada jenis harian ganda tiap hari terjadi dua kali pasang dan dua kali surut yang tingginya masing-masing hampir sama (Nontji, 1987).

Lebih lanjut dijelaskan pasang surut jenis campuran condong ke harian tunggal dalam sehari terjadi satu kali pasang dan satu kali surut sedangkan pasang surut campuran condong ke harian ganda terjadi dua kali pasang dan dua kali surut dalam sehari, tetapi berbeda dalam tinggi dan waktunya. Pasut tipe ini terdapat di Indonesia bagian Timur. Sementara itu Triadmodjo (1999) menginformasikan hal yang sama, bahwa tipe pasut campuran condong ke harian ganda diidentifikasi mendominasi perairan Indonesia bagian Timur. Pasang surut di pesisir Teluk Manado adalah tergolong dalam tipe pasut campuran condong ke harian ganda. Dalam uraian sebelumnya telah disebutkan bahwa perairan Teluk Manado memiliki pola gerak massa air yang dipengaruhi secara signifikan oleh faktor pasut. Fakta yang sama ditemukan dalam penelitian ini, dimana arah dan kecepatan arus perairan pantai sekitar Sario Tumpaan berdinamika pada skala tertentu menurut kondisi pasut. 
Saat massa air bergerak surut di periode bulan kuartir akhir, kecepatan arus tercepat sebesar 1,40 knot ditemukan berlaku pada titik pengamatan 1. Massa air saat itu teramati bergerak ke Barat Laut. Sementara itu, kecepatan arus terlemah sebesar 0,70 knot ditemukan pada titik pengamatan 4 dan 5 dengan arah aliran massa air ke Barat. Selanjutnya saat air laut bergerak pasang kecepatan arus yang tercepat adalah sebesar 0,77 knot pada titik 6 dan mengarah ke Barat. Kecepatan arus terlemah ditemukan berlaku pada titik 5 dengan kecepatan 0,70 knot, dan mengarah ke Barat Daya.

Berkaitan dengan arah arus, hasil pengolahan data menunjukkan bahwa saat massa air bergerak surut pada titik pengamatan 1, 2, 3, 4, 5 mengarah ke Barat Laut dan pada titik pengamatan 6 arah arus ke Barat. Kecenderungan arah arus dominan adalah ke Barat Laut, Gambar 3 menampilkan hasil telaah arah arus secara derkriptif. Gambar 4 memperlihatkan karakteristik arus saat

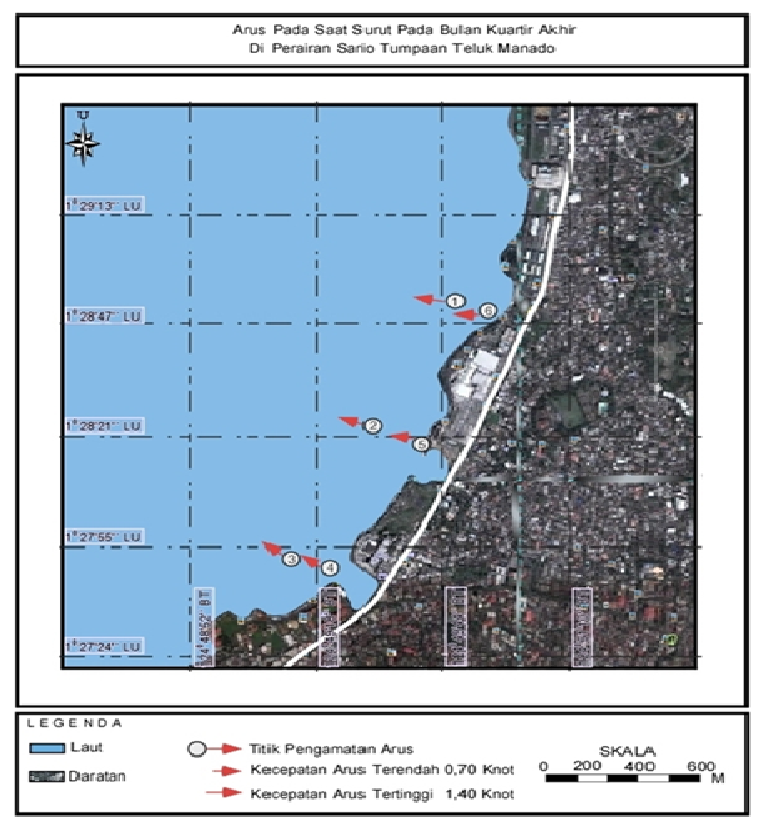

Gambar 3. Arus Saat Surut Pada Bulan Kuartir Akhir di Perairan Sario Tumpaan Teluk Manado.

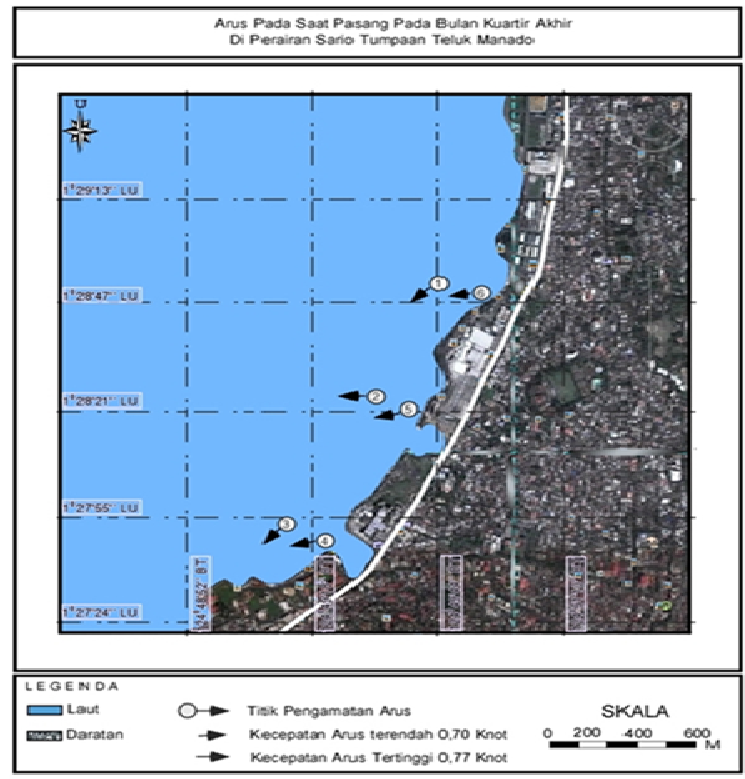

Gambar 4. Arus Saat Pasang Pada Bulan Kuartir Akhir di Perairan Sario Tumpaan Teluk Manado.

pasang dimana pada titik pengamatan 1, 3, 4, 5, 6 arah arus ke Barat Daya dan pada titik pengamatan 2 dan 6 arah arus ke Barat. Sehingga pada saat pasang arah arus lebih dominan ke Barat Daya.

Pada waktu bulan Purnama saat air laut bergerak surut, kecepatan arus tercepat ditemukan pada titik pengamatan 1 dengan kecepatan 1,09 knot dan mengarah ke Utara. Kecepatan terlemah ditemukan berlaku pada titik pengamatan 3, 4, 5 dan 6 dengan kecepatan 0,70 knot. Arah arus pada titik pengamatan 3, 4 dan 5 ditemukan ke Barat Laut, sedangkan pada titik pengamatan 1, 2 dan 6 mengarah ke Utara. Saat air bergerak pasang, kecepatan arus tercepat juga ditemukan pada titik pengamatan 1 dengan kecepatan 0,74 knot. Sementara itu pada titik pengamatan 2, 4, 5 dan 6 kecepatan arus ditemukan lemah dengan kecepatan 0,70 knot. Untuk titik pengamatan 1, 4 dan 6 arah arus ke Barat sedangkan pada titik pengamatan 2, 3 dan 5 arah arus ke Barat Daya. Hasil interpretasi arah arus saat massa air bergerak surut dan pasang pada periode 
bulan purnama selanjutnya ditampilkan seperti dalam gambar 5 dan 6 .

Berdasarkan karakteristik arus yang terjadi waktu bulan Kuartir Akhir saat surut arus mengarah ke Barat dan Barat Laut. Saat pasang arah arus ke Barat dan Barat Daya. Waktu bulan Purnama saat surut arah arus ke Barat Laut dan Utara, dan saat pasang arah arus ke Barat dan Barat Daya. Maka dapat dikatakan pergerakan arus yang berlaku perairan Sario Tumpaan Teluk Manado ini mendapat pengaruh pasang surut.

Seperti yang diinformasikan Rampengan (2009), arus permukaan di Teluk Manado dipengaruhi oleh arus pasut walaupun kerja arus pasut hanya pada bagian mulut teluk, tetapi sirkulasi massa air di ruang lain merupakan respons dari masuk dan keluarnya massa air pada mulut teluk. Dalam penelitian lain, Korwa (2013) dalam studinya di lahan litoral pantai Sindulang Satu melaporkan bahwa pasut memberikan pengaruh terhadap sirkulasi massa air di Teluk Manado. Saat pasang arus mengarah masuk ke Teluk Manado dan

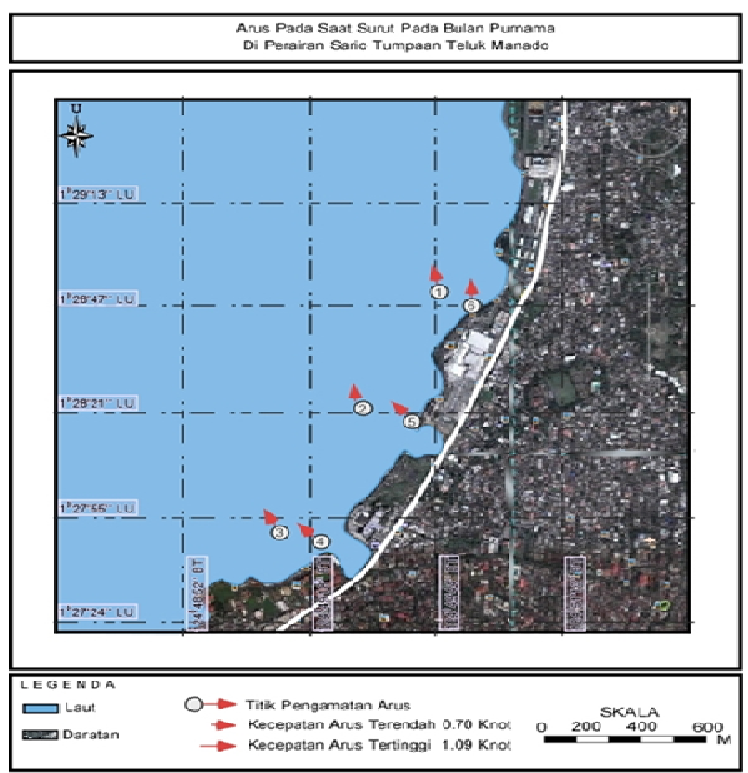

Gambar 5. Arus Saat Surut pada Bulan Purnama di Perairan Sario Tumpaan Teluk Manado.

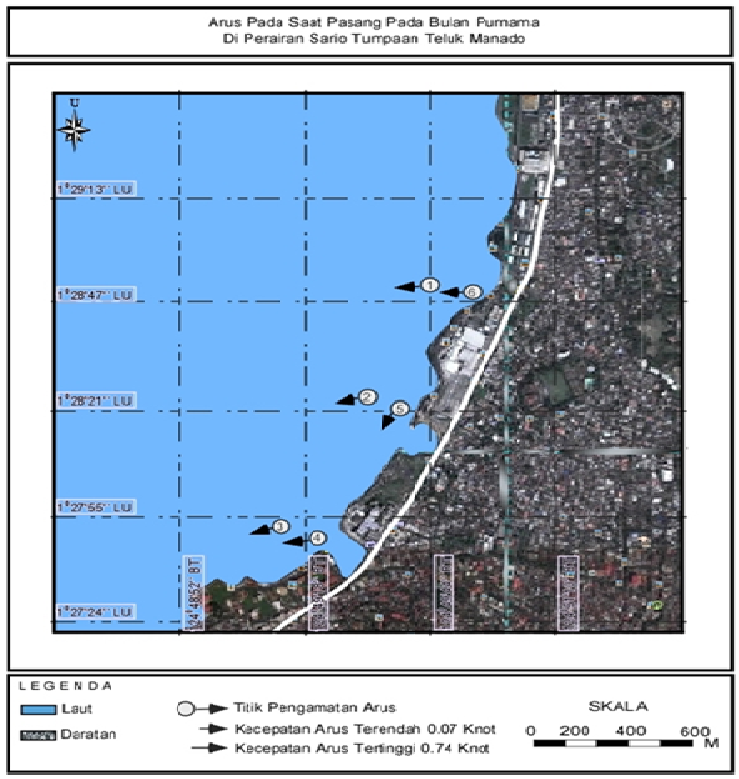

Gambar 6. Arus Saat Pasang pada Bulan Purnama di Perairan Sario Tumpaan Teluk Manado.

saat surut arah arus mengarah keluar teluk.

Lebih lanjut Nontji (1987), menginformasikan bahwa di perairan pantai terutama di teluk-teluk atau selat yang sempit, gerakan naik turunnya muka air laut akan menimbulkan arus pasang surut. Biasa arahnya kurang lebih bolakbalik, jika muka air bergerak naik arus mengalir masuk sedangkan muka air bergerak turun arus mengalir keluar.

Dihubungkan dengan temuan pada penelitian ini, bahwa gerakan massa air di perairan pantai seperti di sekitar Sario Tumpaan yang telah direklamasi, arah arus yang berlaku saat terjadi pasang dan surut di bulan kuartir akhir dan purnama selalu mengarah ke laut dengan arah relatif ke Barat Daya, Barat dan Barat Laut. Fenomena ini berbeda dengan pendapat umum bahwa arah pergerakan massa air akibat pasang surut cenderung bolak-balik secara teoritis, pergerakan massa air ke arah laut di wilayah pantai dikonsepkan sebagai arus 'meretas pantai' (rip current), yang timbul akibat gelombang pecah dengan arah datang 
tegak lurus garis pantai. Namun teramati saat pengamatan, kondisi gelombang seperti itu tidak signifikan. Dengan demikian, pembelokan massa air akibat faktorformasi dan konstruksi dinding reklamasi dapat dipertimbangkan.

\section{KESIMPULAN}

Kesimpulan penelitian ini, karakteristik arus di perairan sekitar Sario Tumpaan dipengaruhi oleh faktor pasang surut. Secara umum saat air bergerak surut kecepatan arus yang terukur lebih cepat dibanding saat air bergerak pasang. Arus dengan kecepatan yang lemah umumnya terukur pada kawasan yang dekat dengan garis pantai, sedangkan saat menjauhi daerah pantai kecepatan arus semakin meningkat. Pergerakan arus yang terjadi saat surut waktu bulan kuartir akhir lebih mengarah ke Barat dan Barat Laut. Saat pasang arus mengarah ke Barat dan Barat Daya. Pada periode bulan purnama saat surut arah arus ke Barat Laut dan Utara, sedangkan saat pasang arah arus cenderung ke arah Barat. Berbeda dengan pola arus yang berlaku secara umum di perairan Teluk Manado, arah arus di perairan Sario Tumpaan saat pergerakan air pasang dan surut selalu mengarah ke laut dengan arah relatif ke Barat Daya, Barat dan Barat Laut.

\section{DAFTAR PUSTAKA}

Ariston, S., 2010, Arus Pasang Surut di Teluk Manado. Skripsi FPIK Unsrat. Manado. 55 hal.

Korwa, J.I.S., 2013. Karakteristik Sedimen Litoral di Pantai Sindulang Satu. Skripsi FPIK Unsrat Manado. 48 hal.

Nontji, A., 1987. Laut Nusantara. Penerbit Djambatan, Jakarta. 368 hal.
Pickard, G.L. dan W.J. Emery, 1982. Descriptive Physical Oceanography An Introduction. Pergamon Press, Oxford. 249 hal.

Rampengan, R.M., 2009. Pengaruh Pasang Surut pada Pergerakan Arus Permukaan di Teluk Manado. Dalam: Jurnal Perikanan dan Kelautan. Vol V (3) FPIK UNSRAT, Manado. Hal 15-19.

Triatmodjo, B., 1999. TeknikPantai. Beta Offset. Yogyakarta.397 hal.

Wyrtki, K. 1961. Physical Oceanography of the South East Asian Waters.Naga Report Vol. 2. The University of California. Scripps, Institution of Oceanography La Jolla California. 195 hal. 